\title{
EHMTI-0008. The international headache society classification of primary headaches is not supported by data and should be revised
}

\author{
E Shevel", D Shevel \\ From 4th European Headache and Migraine Trust International Congress: EHMTIC 2014 \\ Copenhagen, Denmark. 18-21 September 2014
}

The International Headache Society classification of primary headaches in the International ClassificationI of Headache Disorders (ICHD) is almost universally accepted by researchers and clinicians. It is highly unlikely that reputable journals will accept submissions for publication if the cohorts have not been selected strictly according the ICHD. Likewise, in the clinical setting the appropriate treatment is prescribed according to how the patient's headache is classified. But how reliable is the ICHD? As it does not appear to be based on data, its scientific validity is questionable. If indeed it cannot be scientifically validated, then the results of research based on the ICHD would be inaccurate. The practical implications of this are that the research data on the efficacy of migraine drugs is inaccurate. As a result, patients diagnosed according to this classification often receive the incorrect treatment.

No conflict of interest.

Published: 18 September 2014

doi:10.1186/1129-2377-15-S1-D57

Cite this article as: Shevel and Shevel: EHMTI-0008. The international headache society classification of primary headaches is not supported by data and should be revised. The Journal of Headache and Pain 2014 15(Suppl 1):D57.
Submit your manuscript to a SpringerOpen ${ }^{\odot}$ journal and benefit from:

- Convenient online submission

- Rigorous peer review

- Immediate publication on acceptance

- Open access: articles freely available online

- High visibility within the field

- Retaining the copyright to your article

Submit your next manuscript at $>$ springeropen.com

R \& D, Migraine Research Institute, Johannesburg, South Africa

(0) 2014 Shevel and Shevel; licensee Springer. This is an Open Access article distributed under the terms of the Creative Commons Attribution License (http://creativecommons.org/licenses/by/2.0), which permits unrestricted use, distribution, and reproduction in any medium, provided the original work is properly cited. 